\title{
Sistem Pengupahan Buruh Bangunan dalam Prespektif Ekonomi \\ Islam dan Implikasinya Terhadap Kesejahteraan Keluarga (studi \\ kasus Perumahan Mapanget Griya Indah)
}

Oleh: Murni Ngurawan

\begin{abstract}
ABSTRAK
Upah dalam bahasa Arab sering disebut dengan ajrun/ajran yang berarti memberi hadiah/upah. Kata ajran mengandung dua arti, yaitu balasan atau pekerjaan dan pahala. Sedangkan upah menurut istilah adalah uang dan sebagainya yang dibayarkan sebagai balasan jasa atau bayaran atas tenaga yang telah dicurahkan untuk mengerjakan sesuatu.

Tujuan penelitian adalah untuk mengetahui sistem pengupahan buruh bangunan di Perumahan Mapanget Griya Indah, implikasi upah buruh bangunan terhadap kesejahteraan ekonomi, serta pandangan hukum Islam tentang pengupahan buruh bangunan di Perumahan Mapanget Griya Indah. Kemudian kegunaan penelitian ini yakni dapat memberikan manfaat sumbangsih bagi ilmu pengetahuan khususnya dalam bidang Ekonomi Islam dan sebagai bahan rujukan serta pertimbangan kelak, jika menemukan hal yang yang ada kaitannya berhubungan dengan penelitian ini.

Jenis penelitian ini adalah kualitatif deskriptif, maka penelitian ini dimaksudkan untuk menggambarkan, mendipenelitiankan atau melukiskan suatu keadaan, gejala atau kelompok tertentu secara terperinci. Teknik pengumpulan data menggunakan teknik observasi dan wawancara. Sampel dalam penelitian adalah seluruh pekerja di perumahan Mapanget Griya Indah yang terdiri dari 65 orang pekerja yang dipilih menggunakan teknik Purposive Sampling.

Hasil penelitian ini bahwa praktek sistem pengupahan yang terjadi di Perumahan Mapanget Griya Indah ini, dibedakan menjadi 2 bagian ada buruh harian yang upahnya dihitung perhari dan dibayarkan perminggu dari perusahaan. Dan buruh dari pemborong, pihak perusahaan memberikan upah bagi para pemborong yang dihitung perunit rumah sesuai kesepakatan dan mendapatkan upah perminggu sesuai dengan hasil kerja. Adapun implikasi atau akibat dari upah yang mereka dapatkan tersebut sering tidak bisa mencukupi kebutuhan hidup mereka terutama bagi para buruh yang memiliki lebih dari 2 orang anak, dikarenakan mereka harus memenuhi kebutuhan sehari-hari yang sekarang ini semakin mahal dan harus membiayai pendidikan sekolah anak. Apabila dilihat dari pandangan hukum Islam yang bersumber dari Al-Qur'an dan hadis, sistem pelaksanaan pengupahannya dibolehkan dalam islam, tetapi dari segi pembagian upahnya perusahaan ini belum menerapkan sistem pembayaran yang adil dan merata kepada buruh harian dan buruh dari para pemborong sesuai dengan syariat Islam yaitu upah perlu ditentukan secara adil dan tidak dilakukan dengan sewenang-wenangnya.
\end{abstract}




\section{PENDAHULUAN}

\section{A. Latar Belakang}

Pemenuhan kebutuhan merupakan salah satu upaya manusia dalam memenuhi kehidupannya. Kebutuhan ekonomi juga memunculkan berbagi permasalahan yang harus dihadapi. Hal ini di karenakan berbagai pihak, mulai dari subyek itu sendiri hingga pihakpihak 1 ain yang ikut ambil bagian. Misalnya pemerintah, pemilik faktor produksi, pemilik modal serta para pekerja.

Salah satu permasalahan dari masyarakat miskin adalah sistem pengupahan terhadap kerja mereka. Upah dapat kita pandang dari dua segi yaitu, moneter dan yang bukan moneter. Jumlah uang yang diperoleh seorang pekerja selama satu jangka waktu, seperti sebulan, seminggu, atau sehari, mengacu pada upah nominal tenaga kerja. Upah sesungguhnya dari seorang buruh tergantung pada berbagai faktor seperti jumlah upah berupa uang, daya beli uang, dan seterusnya, yang boleh dikatakan terdiri dari jumlah kebutuhan hidup yang sebenarnya diterima oleh seorang pekerja karna kerjanya: "Pekerja kaya atau miskin, diberi imbalan baik atau buruk, sebanding dengan harga nyata, bukan harga nominal atas jerih payahnya. ${ }^{1}$

Teori upah pada umumnya diterima adalah teori produk marjinal. Menurut teori ini upah ditentukan oleh keseimbangan antara kekuatan permintaan dan persediaan. Dengan mengasumsikan penyediaan tenaga kerja dalam suatu jangka waktu yang panjang dan konstan, maka permintaan akan buruh dalam suatu kerangka masyarakat kapitalis, datang dari majikan yang mempekerjakan buruh dan faktor produksi lainnya untuk membuat keuntungan dari kegiatan usahanya.

Selama hasil bersih tenaga kerja lebih besar dari tarif upah itu, majikan akan terus mempekerjakan semakin banyak satuan tenaga kerja. Tentu saja ia akan berhenti mempekerjakan tenaga kerja tambahan pada batas dimana biaya mempekerjakan buruh justru sama dengan (sesungguhnya kurang sedikit dibanding dengan) tambahan yang dilakukannya pada jumlah nilai hasil bersih. "masing-masing majikan, seperti halnya masing-masing konsumen memberi upah buruh yang akan bernilai sama dengan hasil kerja marjinal dengan tarif upah yang berlaku. Hal itu merupakan permintaan semua majikan yang terjadi dalam

${ }^{1}$ Mannan, M. A, Islamic Economics; Theory and Practice, (Jakarta: Edisi I, PT Intermasa, 1992), h. 116 
keseluruhan hubungan dengan persediaan tertentu yang menentukan produk marjinal tenaga secara keseluruhan dan tarif upah dipasaran."2 Pengisapan atau pemerasan (pemanfaatan untuk keuntungan sendiri) terhadap buruh oleh para majikan dilarang oleh Islam. Dalam hadis Nabi Muhammad saw. bersabda :

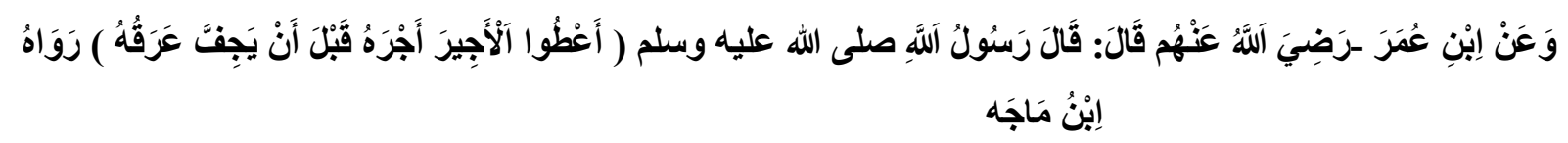

Artinya:

Dari Ibnu Umar Radliyallaahu 'anhu bahwa Rasulullah Shallallaahu 'alaihi wa Sallam bersabda: "Berikanlah kepada pekerja upahnya sebelum mengering keringatnya." Riwayat Ibnu Majah. ${ }^{3}$

Pada kenyataannya, dalam pola suatu masyarakat Islam, upah yang layak bukanlah suatu konsesi, tetapi suatu hak asasi, yang dapat dipaksakan oleh seluruh kekuasaan negara. Penetapan upah dan perumusan produktivitas sesungguhnya hanya merupakan soal penyesuaian yang tepat, ditegaskan kembali bahwa cita-cita dinamik yang mengatur undangundang perburuhan, dan menerima prinsip hak-hak buruh yang diakui seluruh dunia seperti, hak untuk: mogok, mendapatkan upah yang layak, jaminan sosial, laba, dan lain-lainnya.

Diterimanya hak-hak ini berarti bahwa para pekerja akan mempunyai kebebasan tidak terbatas untuk melakukan apa saja. Islam mengutuk penyelewengan atau kecurangan dalam menggelapkan apa pun milik majikan. ${ }^{4}$

Oleh sebab itu Islam menganjurkan untuk berusaha dan bekerja sekuat tenaga dengan segenap kemampuan, sehingga tidak menggantungkan diri kepada orang lain, dan di samping itu pula harus memiliki atau profesionalisme kerja seperti yang dinyatakan oleh Ibrahim atThahani dan Abdul Mu'min bahwa kerja adalah suatu kewajiban. ${ }^{5}$

Karena setiap orang memiliki hak dan kewajiban, hubungan hak dan kewajiban itu diatur dengan kaidah-kaidah untuk menghindari terjadinya bentrokan antar berbagai

\footnotetext{
${ }^{2}$ Ibid., 117
}

${ }^{3} \mathrm{Al}$ Hafidz Abi Abdillah Muhammad bin Yasid al-Qaswiniy, Sunan Ibnu Majah, Juz II, ( No hadis 2443,Kairo: Dakeahlian r Al-Hadist, t.t.), h.817

${ }^{4}$ Ibid., 119

${ }^{5}$ Mustaq Ahmad, Etika Bisnis Islam (Cet. III; Jakarta: Pustaka Al-Kautsar, 2005), h. 10. 
kepentingan, kaidah hukum yang mengatur hubungan hak dan kewajiban dalam hidup bermasyarakat disebut dengan Hukum mu'amalah. ${ }^{6}$

Upah buruh diberikan dengan sistem pembayaran seminggu sekali dikarenakan keperluan hidup dan keluarganya. masa kerja dalam satu hari penuh biasanya dihitung dari pukul 8 pagi sampai 5 sore.

Dalam hal keadilan Azhar Basyir menyarankan terpenuhinya dua model keadilan dalam pemberian upah pada buruh, yaitu: keadilan distributif menuntut agar para buruh yang mengerjakan pekerjaan yang sama dengan kemampuan kadar upah kerja yang berbeda, memperoleh imbalan atau upah yang sama tanpa menutut para buruh untuk memberikan upah yang seimbang dengan tenaga yang diberikan tanpa dipengaruhi oleh hukum penawaran dan permintaan yang menguntungkan pemilik perusahaan. ${ }^{7}$

\section{B. Rumusan dan Batasan Masalah}

Berdasarkan latar belakang masalah yang telah diuraikan di atas, maka permasalahan pokok dalam penelitian ini adalah Bagaimana Sistem Pengupahan buruh bangunan Mapanget Griya Indah?

Untuk menghindari agar permasalahan yang diangkat penulis tidak melebar, maka penulis membatasi masalah dengan membagi beberapa masalah sebagai berikut:

1. Bagaimanakah sistem pengupahan buruh bangunan di Perumahan Mapanget Griya Indah?

2. Bagaimanakah implikasi upah buruh bangunan terhadap kesejahteraan ekomomi?

3. Bagaimanakah Pandangan Hukum Ekonomi Islam tentang pengupahan buruh bangunan di Perumahan Mapanget Griya Indah?

\section{Definisi Operasional dan Ruang Lingkup Penelitian}

Definisi operasional diperlukan untuk menjelaskan makna obyek penelitian. Hal ini bertujuan untuk menghindari timbulnya perbedaan pengertian atau kurang jelasanya makna apabila tidak ada penegasan istilah bagi pembaca.

Maka definisi operasional diungkapkan sekaligus menjelaskan permasalahan yang menjadi ruang lingkup penelitian sebagai berikut :

${ }^{6}$ Ahmad Azhar Basyir, Asas-Asas Hukum Mu'amalah (Hukum Perdata) (Cet. II; Yogyakarta: FH UII, 2004), h. 11

${ }^{7}$ Chairuman Pasaribu dan Suhrawardi K. Lubis, Hukum Perjanjian dalam Islam, (Cet. III; Jakarta: Sinar Grafika, 2004). H. 154. 
1. Sistem Pengupahan Buruh Bangunan adalah Sistem pembayaran upah yang dibayar kepada buruh yang bekerja di perumahan Mapanget Griya Indah, sebagai pembayaran tenaga yang telah disepakati bersama antara pengusaha dan buruh. ${ }^{8}$

2. Prespektif adalah Pandangan ${ }^{9}$

3. Ekonomi Islam adalah perilaku ekonomi secara jujur dan menjaga kepercayaan sesama mitra dagang akan membawa keuntungan dan kemaslahatan yang lebih besar bagi kehidupan masyarakat Islam pada umumnya. ${ }^{10}$

4. Implikasi terhadap kesejahteraan adalah suatu keterlibatan. ${ }^{11}$ Terhadap keadaan, ketentraman, kesenangan hidup, serta kemakmuran ${ }^{12}$ dalam kehidupan rumah tangga.

\section{Tujuan dan Kegunaan}

Tujuan dari penelitian ini adalah:

1. Untuk mengetahui sistem pengupahan buruh bangunan di Perumahan Mapanget Griya Indah

2. Untuk mengetahui Implikasi upah buruh bangunan terhadap kesejahteraan ekonomi

3. Untuk mengetahui bagaimana pandangan Hukum Ekonomi Islam tentang pengupahan buruh bangunan.

Dengan adanya penelitian ini, diharapkan dapat memberikan manfaat sebagai berikut :

1. Secara ilmiah penelitian ini diharapkan dapat memberikan sumbangsih bagi ilmu pengetahuan khususnya dalam bidang ekonomi Islam dan sebagai bahan rujukan serta pertimbangan kelak, jika menemukan hal yang pada kaitannya berhubungan dengan penelitian ini.

2. Secara praktis penelitian ini diharapkan dapat menjadi sumbangan pemikiran bagi Perusahaan Perumahan Mapanget Griya Indah dalam melaksanakan pengupahan buruh bangunan.

3. Sebagai salah satu sumbangan pemikiran penulis dalam bentuk karya ilmiah yang didasarkan pada hasil penelitian, sekaligus memenuhi salah satu persyaratan akademis

\footnotetext{
${ }^{8}$ M.A Mannan, op. Cit., h. 118

${ }^{9}$ Peter Salim \& Yeni Salim, Kamus Bahasa Indonesia, ed. I (Jakarta: Modern English Press, 1991), h. 760.

${ }^{10}$ Departemen Pendidikan \& Kebudayaan, Kamus Bahsa Indonesia, ed. I (Jakarta: Modern English Press, 1991), h. 58.

${ }^{11}$ Ibid., h. 374

12 Ibid., h. 891
} 
bagi penyelesaian studi mahasiswa Program Studi Islam pada Institut Agama Islam Negeri (IAIN) Manado.

\section{TINJAUAN KEPUSTAKAAN}

\section{A. Pengertian Sistem Upah}

Upah dalam bahasa Arab sering disebut dengan ajrun/ajran yang berarti memberi hadiah/upah. ${ }^{13}$ Kata ajran mengandung dua arti, yaitu balasan atau pekerjaan dan pahala. Sedangkan upah menurut istilah adalah uang dan sebagainya yang dibayarkan sebagai balasan jasa atau bayaran atas tenaga yang telah dicurahkan untuk mengerjakan sesuatu. ${ }^{14}$ Upah diberikan sebagai balas jasa atau penggantian kerugian yang diterima oleh pihak buruh karena atas pencurahan tenaga kerjanya kepada orang lain yang berstatus sebagai majikan.

\section{B. Dasar Hukum Sistem Upah}

Dasar hukum upah terdapat dalam Q.S. Al-Ahqaf/46:19.

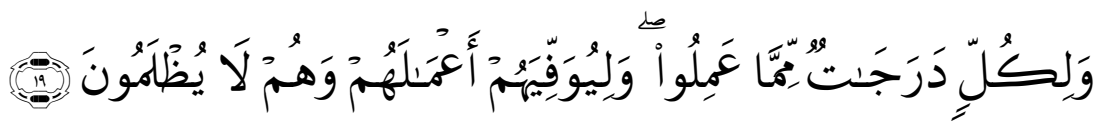

Terjemahnya:

Dan bagi masing-masing mereka derajat menurut apa yang telah mereka kerjakan dan agar Allah mencukupkan bagi mereka (balasan) pekerjaan-pekerjaan mereka sedang mereka tiada dirugikan. ${ }^{15}$

Selanjutnya QS. At Taubah/9:105.
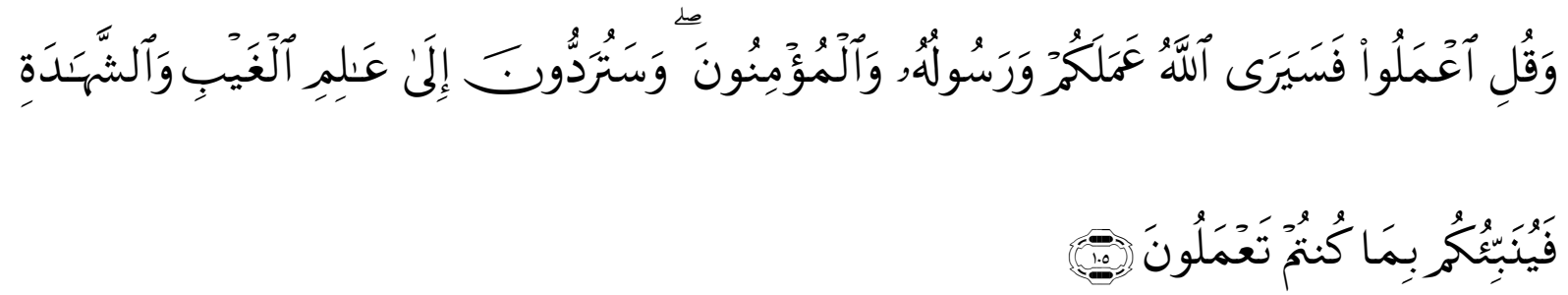

13 Ahmad Warson Munawir, Al-Munawir: Kamus Arab-Indonesia (Cet. ke- 14; Surabaya: Pustaka Progressif, 1997), h. 9.

14 W.. J. S. Purwadarminta, Kamus Umum Bahasa Indonesia (Cet. V; Jakarta: Balai Pustaka, 1976), h. 1132.

${ }^{15}$ Departemen Agama RI, Al-Qur'an dan Terjemahannya, loc. Cit., h. 156. 
Terjemahannya:

Dan Katakanlah: "Bekerjalah kamu, Maka Allah dan Rasul-Nya serta orang-orang mukmin akan melihat pekerjaanmu itu, dan kamu akan dikembalikan kepada (Allah) yang mengetahui akan yang ghaib dan yang nyata, lalu diberitakan-Nya kepada kamu apa yang telah kamu kerjakan. ${ }^{16}$

Dalam pemberian upah yang dibayarkan pada awal waktu sebelum kerja dilaksanakan diperbolehkan, asalkan hal itu dari kesepakatan para pihak yang merupakan salah satu syarat perjanjian, selain itu sudah menjadi kebiasaan yang berlaku sebagaimana ynag dikemukakan Ahmad Azhar Basyir:

Dikisahkan dari Khalifah Umar r.a seorang sahabat Rasulullah saw pakar ekonomi Islam tentang penjelasan upah dan penentuannya adalah riwayat tentang pemuda miskin yang masuk kepada Umar karena ingin jihad dan tidak memiliki dana sama sekali, maka Umar mencarikan untuknya pekerjaan seraya berkata kepada para sahabat, "Siapakah orang akan mempekerjakan atas namaku pemuda ini untuk bekerja diladangnya?" Maka seseorang Anshar berkata, "Saya, wahai Amirul Mukminin!” Umar berkata, "berapa kamu memberinya upah dalam setiap bulan?” Ia menjawab, "Demikian dan demikian.” Umar berkata, “Ambilah dia!. ${ }^{17}$

\section{Rukun dan Syarat Upah}

1. Rukun upah

Rukun merupakan sesuatu yang mesti ada dalam seebuah akad atau transaksi. Tanpa rukun akad tidak akan sah. Layaknya sebuah transaksi ijarah dapat dikatakan sah apabila memenuhi rukun dan syarat. Menurut ulama Hanafiyah rukun dari ijarah itu hanya satu yakni ijab (ungkapan menyewakan) dan qabul (persetujuan atas sewa-menyewa). ${ }^{18}$ Tetapi jumhur ulama mengatakan bahwa rukun ijarah ada empat yaitu: orang yang berakad, ada uang sewa atau imblan, manfaat atas transaksi, dan adanya sighat (ijab dan kabul). ${ }^{19}$ Untuk lebih jelasnya akan dijelaskan secara terperinci sebagai berikut:

a. Orang yang berakad

b. Objek transaksi (manfaat)

${ }^{16}$ Ibid., h. 298

${ }^{17}$ Al Fiqh Al-Iqtishadi Li Amril Mukminin Umar Ibnu Khatab, diteremahkan oleh Jaribah bin Ahmad Al-Harits, Fikih Ekonomi Umar bin Al-Khatab (Cet. 1; Jakarta Timur: KHALIFA Pustaka Al-Kautsar Grup), h. 237.

${ }^{18}$ Wahbah al-Zuhaily, Al-Fiqih al-Islami wa Adillatuh Jilid. IV (Beirut: Dar al Fikr, 1989), h. 731.

${ }^{19}$ Ibid., h. 732. 

c. Imbalan atau upah
d. Sighat yaitu ijab dan qabul
2. Syarat-syarat Upah

\section{Perjanjian Kerja}

\section{Pengertian Perjanjian Kerja}

Gaji atau upah adalah suatu imbalan yang diberikan oleh majikan kepada pekerja sebagai pembayaran untuk jasa tenaga kerja. Sebelum mendapatkan gaji atau upah biasanya pihak yang terlibat dalam pekerjaan ini membuat perjanjian atau sering juga dikatakan kontrak kerja.

Perjanjian kerja yang dalam bahasa Belanda disebut Arbeidsoverenkoms, mempunyai beberapa pengertian. Pasal 1601 a KUHPerdata memberikan pengertian sebagai berikut:

Perjanjian kerja adalah suatu perjanjian dimana pihak kesatu (pekerja), mengikatkan dirinya untuk dibawah pihak yang lain, si majikan untuk suatu waktu tertentu melakukan pekerjaan dengan menerima upah. ${ }^{20}$

UU No.13 Tahun 2003 tentang Ketenagakerjaan, Pasal 1 angka 14 memberikan pengertian yakni:

Pekerjaan kerja adalah suatu perjanjian antara pekerja/buruh dan pengusaha atau pemberi kerja yang memuat syarat-syarat kerja hak dan kewajiban kedua belah pihak. ${ }^{21}$

\section{Syarat Sahnya Perjanjian Kerja}

Sebagai bahan dari perjanjian pada umumnya, maka perjanjian kerja harus memenuhi syarat sahnya perjanjian sebagaimana diatur dalam Pasal 1320 KUHPerdata. Ketentuan ini juga tertuang dalam Pasal 52 ayat 1 UU No.13 Tahun 2003 tentang Ketenagakerjaan yang menyebutkan bahwa perjanjian kerja dibuat atas dasar:

a. Kesepakatan kedua belah pihak

b. Kemampuan atau kecakapan melakukan perbuatan hukum

c. Adanya pekerjaan yang diperjanjikan

d. Pekerjaan yag diperjanjikan tidak boleh bertentangan dengan ketertiban umum, kesusilaan dan ketentuan peraturan perundangan-perudangan yang berlaku. ${ }^{22}$

\footnotetext{
${ }^{20}$ KUHPerdata pasal 1601a, (Jakata: Permata Press cet.1 2008), h.366

${ }^{21}$ UU No.13 Tahun 2003 tentang Ketenagakerjaan Pasal 1 angka 14

${ }^{22}$ Ibid.,h. 71
} 


\section{METODOLOGI PENELITIAN}

\section{A. Jenis dan Pendekatan Penelitian}

Jenis penelitian ini adalah deskriptif kualitatif, hal ini dimaksudkan agar permasalahan yang dijadikan fokus akan dikaji lebih mendalam, sehingga akan melihat bagaimana sistem pengupahan buruh bangunan, bagaimana Implikasih upah buruh bangunan terhadap kesejahteraan ekonomi serta, bagaimana pandangan Hukum Ekonomi Islam tentang Pengupahan buruh bangunan di Perumahan Mapanget Griya Indah.

Penelitian ini menggunakan pendekatan kualitatif.Artinya data yang diangkat bukan berupa angka tapi berasal dari naskah wawancara, catatan lapangan, sehingga yang menjadi tujuan dari penelitian kualitatif ingin menggambarkan realita empirik dibalik fenomena secara mendalam, rinci dan tuntas.Oleh karena itu penggunaan pendekatan kualitatif ini adalah dengan mencocokkan antara realita empirik dengan teori yang berlaku dengan menggunakan metode deskriptif. ${ }^{23}$ Melalui pendekatan tersebut, penulis inginmemperoleh data berdasarkan situasi penelitian yang wajar tanpa ada upaya manipulasi.

\section{B. Populasi dan Sampel}

Populasi dalam penelitian ini adalah seluruh jumlah pekerja di Perumahan Griya Mapanget Indah yang terdiri dari enam puluh lima orang pekerja. Penarikan sampel ini digunakan dengan cara Purposive Sampling, yaitu menentukan subjek atau objek sesuai tujuan. ${ }^{24}$ Yang menjadi subjek yaitu pemborong Perumahan sedangkan objek adalah pekerja buruh bangunan. Penarikan sampel ini dilakukan secara khusus menargetkan informan yang berkaitan langsung dengan rumusan masalah ataupun dengan topik penelitian.

\section{Sumber data}

Sumber data dalam menyelesaikan penelitian ini dibagi dalam dua macam yaitu sumber data primer dan data sekunder.

1. Data primer adalah data yang diambil secara langsung melalui beberapa teknik pengumpulan data terhadap fakta yang berhubungan langsung dengan penelitian ini, yaitu pengusaha perumahan dan buruh bangunan

2. Data sekunder adalah data yang diambil yang seluruhnya dalam bentuk dokumendokumen (dokumentasi, hasil wawancara dengan pengusaha dan buruh bangunan). Di Perumahan Mapanget Griya Indah

${ }^{23}$ Lexy Moleong, Metode Penelitian Kualitatif, (Cet. IX; Bandung: Remaja Rosdakarya, 2000), h. 131

${ }^{24}$ Djam'an Satori \& Aan Komariah, Metodologi Penelitian Kualitatif (Cet. ke-3; Bandung: Alfabeta. 2011), h. 47. 
Data dapat diperoleh langsung dari lapangan termasuk laboratorium, data ini disebut data primer, sedangkan dari bahan bacaan atau bahan tertulis yang bukan buku acuan teori disebut data sekunder.

\section{Metode Pengumpulan Data}

Teknik pengumpulan data merupakan salah satu langkah utama dalam penelitian, karena tujuan utama dari penelitian adalah mendapatkan data. Teknik pengumpulan data dimaksudkan untuk memperoleh informasi atau data yang akurat, relevan, dan reliabel.

Penelitian menggunakan teknik pengumpulan data dengan melakukan penelitian lapangan. Untuk mendapatkan data yang dibutuhkan dalam penelitian ini, digunakan beberapa teknik pengumpulan data yaitu :

1. Dokumentasi

2. Penelitian lapangan (Field Research)

Dengan keakuratan data yang terjaring dari metode ini dapat dipertanggung jawabkan secara ilmiah. Beberapa teknik pengumpulan data-data melalui metode penelitian lapangan yang digunakan penulis meliputi :

1. Observasi

2. Wawancara

\section{E. Teknik Analisa data}

Analisis data merupakan proses mencari dan menyusun secara sistematis data yang diperoleh dari hasil wawancara, catatan dilapangan, dan bahan-bahan lain, sehingga dapat mudah dipahami dan temuannya dapat diinformasikan kepada orang lain. Adapun teknik analisis data yang digunakan dalam penelitian ini adalah:

1. Reduksi data ( data reduction):

2. Penyajian data (data display):

3. Conclusion drawing/verivication:

\section{HASIL PENELITIAN DAN PEMBAHASAN}

\section{A. Pelaksanaan Sistem Pengupahan Buruh Bangunan di Perumahan Mapanget Griya} Indah.

Dalam hasil penelitian yang saya tanyakan kepada bapak Berty Kalesaran selaku developer atau penanggung jawab atas upah dan bangunan perumahan di Perumahan Mapanget Griya Indah mereka memiliki 65 orang pekerja atau buruh di antaranya 35 orang buruh tetap, 25 orang buruh dari para pemborong dan 5 orang pemborong diperumahan tersebut. Rata-rata usia pekerja atau buruh yang terdapat di Perumahan Mapanget Griya Indah 20 tahun sampai dengan umur 58 tahun. Adapun pihak perusahaan Perumahan 
Mapanget Griya Indah ini bekerja sama dengan Bank BTN atau Bank Tabungan Negara dan BNI atau Bank Negara Indonesia.

Berdasarkan hasil penelitian penulis menemukan dua sistem upah buruh yang berlaku di Perumahan Mapanget Griya Indah yaitu buruh harian, dan buruh pemborong atau buruh yang berasal dari pemborong pekerjaan.

1. Buruh harian adalah buruh yang upahnya dibayar harian dari perusahaan atau dari pihak perumahan itu sendiri. Buruh harian ini mengerjakan semua pekerjaan yang ada di Perumahan Mapanget Griya Indah, baik pekerjaan kayu (seperti bikin konseng, pemasangan jendela, pintu), pekerjaan bangunan (seperti membuat pondasi rumah, bikin besi, susun olobrik, pasang kap) maupun pekerjaan yang ditinggalkan dari para pemborong.

2. Buruh pemborong yaitu buruh yang berasal dari para pemborong perumahan yang ada di Perumahan Mapanget Griya Indah, buruh pemborong ini mengerjakan apa yang diperintahkan oleh pemborongnya atau biasa dikenal dengan kepala bas bangunan saja.

Adapun dalam pekerjaan buruh bangunan mempunyai dua bidang pekerja yaitu kepala tukang biasa disebut dengan bas, dan buruh pembantu kepala tukang biasa disebut dengan kenek. Di bawah ini rincian upah buruh dari pemborong dan upah buruh harian sesuai dengan bidang pekerjaannya:

\begin{tabular}{|l|l|l|l|l|l|}
\hline Nama & \multicolumn{1}{|c|}{ Status Buruh } & Usia & $\begin{array}{c}\text { Lama } \\
\text { bekerja }\end{array}$ & \multicolumn{1}{|c|}{$\begin{array}{c}\text { 25 Upah } \\
\text { harian }\end{array}$} & Agama \\
\hline An & Harian (bas) & 35 tahun & 4 tahun & Rp. 100.000,- & Kristen \\
\hline Dani & Harian (kenek) & 26 tahun & 2 tahun & Rp. 80.000,- & Islam \\
\hline Vit & Harian (kenek) & 35 tahun & 4 tahun & Rp. 80.000,- & Kristen \\
\hline Haris & Harian (bas) & 37 tahun & 5 tahun & Rp. 100.000,- & Islam \\
\hline Apsoni & Harian (kenek) & 35 tahun & 2 tahun & Rp. 80.000,- & Kristen \\
\hline Koko & $\begin{array}{l}\text { Dari pemborong } \\
\text { (bas) }\end{array}$ & 38 tahun & 7 tahun & Rp. 150.000,- & Kristen \\
\hline Nixon & $\begin{array}{l}\text { Dari pemborong } \\
\text { (buruh kenek) }\end{array}$ & 25 tahun & 3 tahun & Rp. 100.000,- & Kristen \\
\hline
\end{tabular}

${ }^{25}$ Wawancara dengan Para Pekerja Tetap yang bekerja diPerumahan Mapanget Griya Indah. Wawancara dilakukan pada hari sabtu jam 17.00. Tanggal 19/12/2014. 


\begin{tabular}{|c|c|c|c|c|c|}
\hline Risko & Harian (bas) & 38tahun & 5tahun & Rp. 100.000,- & Islam \\
\hline Aksay & Harian (bas) & 38tahun & 5tahun & Rp. 100.000,- & Islam \\
\hline Rosidi & Harian (bas) & 40tahun & 8tahun & Rp. 100.000,- & Islam \\
\hline Rocky & $\begin{array}{l}\text { Dari pemborong } \\
\text { (bas) }\end{array}$ & 40tahun & 8tahun & Rp. 150.000,- & Kristen \\
\hline Didi & $\begin{array}{l}\text { Dari pemborong } \\
\text { (bas) }\end{array}$ & 45tahun & 10tahun & Rp. 150.000,- & Islam \\
\hline Ruben & $\begin{array}{l}\text { Dari pemborong } \\
\text { (kenek) }\end{array}$ & 30tahun & 3tahun & Rp. 100.000,- & Kristen \\
\hline Risky & $\begin{array}{l}\text { Dari pemborong } \\
\text { (kenek) }\end{array}$ & 33tahun & 3tahun & Rp. 100.000,- & Islam \\
\hline Jemi & Harian (bas) & 42tahun & 10tahun & Rp. 100.000,- & Kristen \\
\hline Andi & Harian (bas) & 38tahun & 7tahun & Rp. 100.000,- & Kristen \\
\hline Iwan & $\begin{array}{l}\text { Dari pemborong } \\
\text { (bas) }\end{array}$ & 40tahun & 5tahun & Rp. 150.000,- & Islam \\
\hline Noldi & $\begin{array}{l}\text { Dari pemborong } \\
\text { (kenek) }\end{array}$ & 28tahun & 2tahun & Rp. 100.000,- & Kristen \\
\hline Deswan & $\begin{array}{l}\text { Dari pemborong } \\
\text { (bas) }\end{array}$ & 45tahun & 7 tahun & Rp. 150.000,- & Islam \\
\hline Hawe & $\begin{array}{l}\text { Dari pemborong } \\
\text { (bas) }\end{array}$ & 40tahun & 5 tanun & Rp. 150.000,- & Kristen \\
\hline
\end{tabular}

Sesuai tabel di atas dapat disimpulkan bahwa pelaksanaan upah di Perumahan Mapanget Griya Indah ini adanya ketidak samaan upah antara upah buruh harian dengan buruh dari para pemborong. standart upah yang diberikan kepada buruh harian sangatlah rendah dengan kerja yang lebih sulit dari para pekerja buruh borongan. Para buruh harian bekerja menurut permintaan dan aturan dari pihak perusahaan. Berdasarkan hasil penelitian penulis pembayaran upah ini sudah berlaku sejak lama, sebagian buruh harian mengatakan bahwa upah mereka terkadang tidak diberikan tepat waktu atau biasanya mereka mendapat upahnya lewat dari seminggu mereka kerja. 
Dari hasil wawancara penulis dengan pihak penanggung jawab perumahan atau devoloper Perumahan Mapanget Griya Indah upah yang mereka berikan kepada buruh berasal dari beberapa pihak yaitu: dari pihak Perusahaan itu sendiri, ada pula hasil dari jual perumahan secara tunai, dari uang muka pembelian perumahan, dari tagihan perumahan secara kredit, adapula pembelian lahan lebih dari perumahan, dan terkadang dari uang pribadi Developer.

Adapun dalam sistem pembayaran upah atau gaji kepada para pemborong di Perumahan Mapanget Griya Indah mereka memiliki 2 sistem yaitu:

1. Pihak perusahaan memberikan upah bagi para pemborong 8 juta untuk upah kerja bangunan yang dihitung perunit rumah, adapun bahan bangunanya ditanggung oleh pihak perusahaan dengan kesepakatan mereka mendapatkan upah perminggu sesuai hasil kerja.

2. Pihak perusahaan memberikan uang sebesar Rp. 35.000.000,- untuk satu unit perumahan kepada pemborong dengan ketentuan bahan-bahan bangunan perumahan, dan buruh pemborong ditanggung oleh pihak pemborong. Akan tetapi dalam sistem pembayaran ini pihak pemborong mengerjakan duluan pekerjaannya tanpa uang dari perusahaan dengan menggunakan uang pribadi dari pemborong itu sendiri. Pihak perusahaan akan membayar uang ketika pekerjaan para pemborong sudah mencapai $50 \%$ sesuai dengan kesepakatan bersama. ${ }^{26}$

Contoh ilustrasi Sistem Pembayaran upah buruh:

Pak Jalil mendapatkan borongan 8 unit Perumahan bangunan dari Perusahaan PT Axelindo Pratama Manado, untuk pembangunan perumahan tersebut pihak perusahaan menetapkan upah kerja dalam 1 unit rumah harganya Rp. 8.000.000,-. Dengan bahan-bahan bangunannya ditanggung oleh perusahaan itu sendiri. Pihak pemborong menyelesaikan 1 unit rumah selama 3 minggu dengan jumlah buruh yang dimiliki 5 buruh, uang yang diberikan kepada buruh pemborong tersebut diambil dari perusahaan dengan melihat hasil kerja yang mereka kerjakan. Seperti dalam seminggu mereka menyelesaikan pembangunan pondasi Rp. 500.000,- per satu unit rumah, susunan olobrik Rp. 1.300.000,- , sopi-sopi sampai kap Rp. 600.000,-, maka dalam seminggu pemborong mendapat upah dari perusahaan sebesar Rp. 2.400.000,- untuk penyelesaian satu unit perumahan.

\footnotetext{
${ }^{26}$ Hasil wawancara dengan pemborong bangunan perumahan Mapanget Griya Indah Bpk Asis pada hari sabtu jam 17.00, Tanggal 19/12/2014.
} 
Sesuai dengan penjelasan diatas berikut ini adalah rincian anggaran upah untuk borongan per satu unit perumahan tipe $36::^{27}$

\begin{tabular}{|c|c|c|c|}
\hline No & Uraian pekerjaan & $\begin{array}{c}\text { Banyaknya } \\
\text { (volume kerja) }\end{array}$ & Jumlah \\
\hline 1 & Pondasi & $100 \%$ & Rp. $\quad 500.000,-$ \\
\hline 2 & Penyusunan olobrik & $100 \%$ & Rp. 1.300.000,- \\
\hline 3 & $\begin{array}{l}\text { Plesteran sekalian leburan dinding } \\
\text { (aci) }\end{array}$ & $100 \%$ & Rp. 1.650.000,- \\
\hline 4 & Sopi-sopi - kap & $100 \%$ & Rp. $\quad 600.000,-$ \\
\hline 5 & Pembuatan Teras (place) & $100 \%$ & Rp $\quad 800.000,-$ \\
\hline 6 & Pemasangan jendela dan pintu & $100 \%$ & Rp. $\quad 300.000,-$ \\
\hline 7 & Cor slof & $100 \%$ & $\begin{array}{ll}\text { Rp. } & 150.000,-\end{array}$ \\
\hline 8 & Timbun & $100 \%$ & $\begin{array}{ll}\text { Rp. } & 150.000,-\end{array}$ \\
\hline 9 & Pembuatan WC & $100 \%$ & $\begin{array}{ll}\text { Rp. } & 500.000,-\end{array}$ \\
\hline 10 & Plafon & $100 \%$ & $\begin{array}{ll}\text { Rp. } & 500.000,-\end{array}$ \\
\hline 11 & Pemasangan Tehel & $100 \%$ & Rp. $\quad 650.000,-$ \\
\hline 12 & Pemasangan kaca & $100 \%$ & Rp. $\quad 100.000,-$ \\
\hline 13 & Pemasangan lesplank & $100 \%$ & Rp. $\quad 150.000,-$ \\
\hline 14 & Cat & $100 \%$ & Rp. $\quad 250.000,-$ \\
\hline 15 & Plesteran pondasi & $100 \%$ & Rp. $\quad 100.000,-$ \\
\hline 16 & Finising & $100 \%$ & Rp. $\quad 300.000,-$ \\
\hline & Sub Total & & Rp. 8.000.000,- \\
\hline
\end{tabular}

\section{B. Implikasi Upah Buruh Bangunan terhadap Kesejahteraan Ekonomi.}

Dari hasil penelitian dan informasi yang di dapatkan dari 20 orang buruh bangunan menyangkut implikasi upah atau akibat upah yang di dapatkan oleh buruh bangunan di

${ }^{27}$ Hasil wawancara dengan bapak jalil sebagai pemborong Perumahan Mapanget Griya Indah pada hari Rabu tanggal 28 Januari 2015. 
Perumahan Mapanget Griya Indah. Ada 14 orang buruh bangunan mengatakan bahwa upah yang mereka dapatkan tersebut sering tidak bisa mencukupi kebutuhan hidup mereka. Terutama bagi para buruh yang memiliki lebih dari 2 orang anak dikarenakan mereka harus memenuhi kebutuhan sehari-hari yang sekarang ini semakin mahal dan harus membiayai pendidikan sekolah anak, itu yang membuat upah yang didapatkan parah buruh itu tidak mencukupi. Sedangkan para buruh yang memiliki 2 orang anak juga merasa kebutuhan ekonomi mereka tidak terpenuhi dengan upah yang di dapatkan dari hasil pekerjaan buruh bangunan tersebut, karena menurut mereka kebutuhan ekonomi yang sekarang semakin mahal dan upah yang mereka dapatkan masih terlalu rendah untuk memenuhi kehidupan mereka. Sedangkan dari hasil wawancara dengan 20 orang buruh bangunan 6 dari 20 orang tersebut mengatakan bahwa upah yang mereka dapatkan bisa mencukupi kebutuhan hidup ekonomi mereka karena 6 orang buruh bangunan tersebut ada yang belum berumah tangga, sehingga mereka mengatakan bahwa upah tersebut sudah bisa mencukupi kebutuhan hidup mereka sehari-hari, selain itu ada juga yang sudah berumah tangga akan tetapi upah yang mereka dapatkan lebih tinggi dari 14 buruh bangunan diatas, karena mereka adalah buruh bangunan dari pihak pemborong perumahan bukan dari buruh bangunan perusahaan. ${ }^{28}$

Economi welfare adalah kesejahteraan ekonomi yang tercapai sebagai hasil dari penerimaan bagian yang wajar daripada hasil-hasil produksi yang seimbang dengan waktu, prestasi atau pengorbanan dan kecerdasan yang dipakai atau yang dicurahkan dalam proses produksi.

Welfare state sendiri memiliki definisi yang beragam, ada yang menyebutkan bahwa welfare state merupakan kondisi sejahtera yang merujuk pada kesejahteraan sosial, sebagian lain menyatakan welfare state sebagai suatu program yang dilaksanakan oleh pemerintah maupun lembaga social lainnya, untuk membangun infrastruktur atau memberi tunjangan demi tercapainya kesejahteraan social. Maka konsep walfare state ini sangatlah tergantung pada seberapa besar peran pemerintah dalam membuat negaranya menjadi negara yang sejahtera. Dalam melaksanakan fungsi kesejahteraan umum, sejatinya seluruh aktivitas negara secara langsung ditujukan kepada kehidupan dan kesejahteraan rakyat melalui pemeliharaan kesehatan dan kesejahteraan, untuk perumahan dan kebutuhan hidup lainnya, serta jaminan social ekonomi, dan lainnya. ${ }^{29}$

\footnotetext{
${ }^{28}$ Hasil wawancara dengan para buruh pembantu kepala tukang di Perumahan Mapanget Griya Indah pada hari Kamis tanggal 29 Januari 2015.

${ }^{29} \mathrm{Http}: / /$ eva-avgvsta.blogspot.co.id/2012/11/welfare-state.html. Di ambil hari kamis tanggal 4 Februari 2016, pukul: 13.00
} 
Menurut hasil analisa penulis problem yang langsung menyentuh kaum buruh atau pekerja adalah rendahnya atau tidak sesuainya pendapatan upah yang diperoleh dengan tuntutan untuk memenuhi kebutuhan hidupnya beserta tanggungannya. Yakni kebutuhan hidup semakin meningkat, sementara upah yang diterima kecil. Upah itu merupakan unsur terpenting yang berpengaruh terhadap kehidupan pekerja karena upah menjadi sumber pendapatan untuk memenuhi kebutuhan hidup pekerja dan keluarganya baik berupa sandang, pangan, perumahan maupun kebutuhan lain. Yang lebih penting lagi bahwa dampak negatif dari upah minimum sangat dirasakan oleh buruh bangunan yang bekerja di Perumahan Mapanget Griya Indah. Implikasi atau akibat yang menyebabkan ketidakcukupan upah yang mereka terima terhadap kesejahteraan Ekonomi yaitu: Mahalnya harga bahan baku, kebutuhan sehari-hari semakin meningkat sedangkan upah yang mereka terima masih rendah, untuk membeli kebutuhan keluarga sendiri masih kurang, untuk biaya pendidikan anak tidak cukup.

\section{Sistem Pengupahan Buruh Bangunan dalam Pandangan Ekonomi Islam}

Islam memberikan pedoman bagi kehidupah manusia dalam bidang perekonomian tidak memberikan landasan yang bersifat praktis, berapa besarnya upah yang harus diberikan kepada buruh untuk mencukupi kebutuhan hidup. Namun Islam memperbolehkan seseorang untuk mengontrak tenaga pekerja atau buruh agar mereka bekerja untuk orang tersebut.

Seperti yang terdapat di Perumahan Mapanget Griya Indah Mapanget upah kerja bagi buruh yang diberikan oleh perusahaan adalah hasil kesepakatan pengusaha dengan beberapa ketentuan yang berlaku pada para pekerja buruh yang diberikan sesuai dengan hasil kerja. Dengan pembayaran upahnya berdasarkan upah harian yang sudah ditetapakan dan ada pula dari hasil kerja dengan ukuran meter atau banyaknya yang dikerjakan bagi para pemborong.

Misalnya bagi pekerja buruh tetap atau buruh harian mereka mengerjakan semua pekerjaan yang diperintahkan oleh pengawas atau pihak dari perusahaan, sedangkan pekerja buruh borongan mengerjakan pekerjaan yang sudah ditetapkan oleh pemborongnya. Tidak terdapatnya keadilan antara upah pekerja buruh tetap atau buruh harian dengan buruh borongan yang diberikan perusahaan. Standar upah yang adil untuk kehidupan para buruh tetap atau buruh harian yang tidak sesuai dengan jerih payah mereka.

Menetapkan standar upah yang adil bagi seorang pekerja sesuai dengan kehendak syari'ah bukanlah perkara yang mudah apalagi bagi pekerja buruh bangunan yang upahnya 
didapatkan masih sangat minim untuk memenuhi kebutuhan hidup mereka sehari-hari. Konsep upah yang adil dalam dunia kerja. Kesulitan penetapan upah ini pernah terjadi dalam penetapan upah Khalifah Abu Bakar al-Shiddiq. Umar bin Khattab bersama sahabat lain menetapkan gaji Abu Bakar dengan standar yang mencukupi kehidupan seorang muslim golongan menengah.

Penetapan gaji ini masih samar-samar sehingga Abu Bakar meminta ukuran penghasilan pedagang, yaitu 12 dirham setiap hari. Standar Abu Bakar ini adalah kerja yang memungkinkan seseorang mendapatkan penghasilan. Penghasilan harian atau bulanan seseorang, secara umum dalam masyarakat bekerja dapat menjadi standar pengupahan secara pantas. Berikut ini terdapat standar upah yang adil baik dalam pemandangan Islam maupun penentuan upah minimum dari pemerintah tentang standar upah buruh.

1. Standar upah yang adil dalam pandangan syari'at Islam

Upah merupakan hak yang sangat mendasar bagi pekerja/buruh, upah perlu ditentukan secara adil dan tidak dilakukan sewenang-wenangnya, Keadilan Islam, tidak membenarkan jika seorang pekerja/buruh yang telah membanting tulang dan bercucuran keringat, tidak mendapatkan upah dari jeri payahnya itu dikurangi, atau ditunda pemberiannya. ${ }^{30}$ Kadar upah buruh yang adil adalah yang setimpal dengan bidang kerja bergantung kepada kualitas buruh yang merangkumi aspek fisikal, kemahiran latihan dan mentalnya dan kebolehannya melebihi kadar keperluan menampung perbelanjaan diri dan keluargannya. ${ }^{31}$

Sekaligus merupakan kewajiban bagi majikan yang harus segera membayar upah setelah pekerjaannya selesai dilaksanakan, akan tetapi Islam menolak anggapan keadilan dalam rangka pemberian upah adalah mendapatkan imbalan yang sama antara yang satu dan lainnya. Juga anggapan bahwa pekerja bukan hanya semata-mata untuk mendapatkan imbalan yang bersifat materi saja. Akan tetapi untuk mendapatkan pahala yang diungkapkan oleh Sayyid Qutub sebagai berikut:

Keadilan yang mutlak pasti membutuhkan perbedaan imbalan ada kelebihan sebagian yang lainny, disamping realisasi keadilan dari segi kemanusiaan berupa pemberian kesempatan yang merata dan meluas kepada masyarakat, Islam menolak menjadikan materi sebagai imbalan bagi nilai-nilai itu (bekerja) dan tidak mau

\footnotetext{
${ }^{30}$ Yusuf Qardawi, op. Cit., h. 231.

${ }^{31}$ Surtahman Kastin Hassan, op. Cit., h. 8-9
} 
mengubah kehidupan ini menjadi sekedar nilai dengan sepotong roti, kepuasan jasmani atau sejumlah uang. ${ }^{32}$

Upah yang adil sebenarnya merupakan upah yangmengacu pada jasa dari buruh yang dipengaruhi oleh beberapa hal, seperti jumlah yang diterima, daya beli uang dan sebagainya. Yang merupakan alat untuk memenuhi kebutuhan hidup yang sebenarnya dari pekerja, juga pada kenyataannya dalam pola masyarakat Islam. Upah bukan hanya merupakan imbalan, tetapi merupakan hak asasi yang dalam penetapannya terdapat 3 (tiga) asas yaitu, asas keadilan, asas kelayakan dan asas kebijakkan. ${ }^{33}$

a. Asas keadilan

b. Asas kelayakan

c. Asas kebajikan

Sedangkan kebajikan berarti menuntut agar jasa yang diberikan mendatangkan keuntungan besar kepada buruh supaya bisa diberikan bonus. ${ }^{34}$

Dalam perjanjian kedua belah pihak diperingatkan untuk bersikap jujur dan adil dalam semua urusan mereka, sehingga tidak terjadi tindakan aniaya yang merugikan kepentingan pengusaha dan buruh. Penganiayaan terhadap buruh berarti bahwa mereka tidak dibayar secara adil dan bagian yang sah dari hasil kerjasama sebagai jatah dari hasil kerja buruh. Sedangkan yang dimaksud dengan penganiayaan terhadap pengusaha adalah mereka dipaksa buruh untuk membayar upah buruh dari kemampuan mereka.

Berdasarkan uraian di atas, maka dapat disimpulkan bahwa untuk mempertahankan upah pada suatu standar yang wajar, Islam memberikan kebebasan sepenuhnya dalam mobilitas tenaga kerja sesuai dengan perjanjian yang disepakati (akad). Mereka bebas bergerak untuk mencari penghidupan dibagian mana saja di dalam negaranya. Tidak ada pembatasan sama sekali terhadap perpindahan mereka dari satu daerah ke daerah lainnya di negara tersebut guna mencari upah yang lebih tinggi.

Metode kedua yang dianjurkan oleh Islam dalam menentukan standar upah diseluruh negeri adalah dengan benar-benar memberi kebebasan dalam bekerja. Setiap orang bebas memilih pekerjaan apa saja yang sesuai dengan pilihannya serta tidak ada pembatasan yang

\footnotetext{
${ }^{32}$ Sayyid Qutub, op. Cit., h. 39.

${ }^{33}$ Ahmad Azhar Basyir, Refleksi atas Pemikiran Keislaman, (Cet. IV; Bandung: Mizan, 1416/1996M), h. 191 .

${ }^{34}$ Ahmad Azhar Basyir, op. Cit., h. 195.
} 
mungkin dapat menciptakan kesulitan-kesulitan bagi para pekerja dalam memilih pekerjaan atau daerah kerjanya yang sesuai.

2. Peraturan pemerintah dalam penetapan upah bagi buruh

Penetapan upah bagi buruh telah diatur dalam perundang-undangan ketenagakerjaan yang terinci sebagai berikut ini: $:^{35}$

a. Pasal 2 Peraturan Pemerintah Nomor 8 tahun 1981 tentang perlindungan upah, bahwa hak menerima upah timbul pada saat adanya hubungan kerja dan berakhir pada saat hubungan kerja putus.

b. Pada pasal 3 Peraturan Pemerintah Nomor 8 tahun 1981 tentang Perlindungan Upah, bahwa Pengusaha juga tidak boleh mengadakan diskriminasi upah bagi buruh baik laki-laki dan wanita untuk jenis pekerjaan yang sama.

c. Pasal 93 ayat (1) Undang-undang Nomor 13 tahun 2003 tentang Ketenagakerjaan, menyatakan bahwa upah tidak dibayar apabila buruh tidak melakukan pekerjaan atau disebut asas no work no pay

d.Pada pasal 90 ayat (1) Undang-undang Nomor 13 tahun 2003 tentang ketenagakerjaan, bahwa pengusaha dilarang membayar upah lebih rendah dari ketentuan upah minimum.

e. Pada pasal 94 Undang Nomor 13 tahun 2003 tentang ketenagakerjaan, menyatakan bahwa komponen upah terdiri dari upah pokok dan tunjangan tetap, dengan formulasi upah pokok minimal $75 \%$ (tujuh puluh lima persen) dari jumlah upah pokok dan tunjangn tetap.

f. Pada pasal 95 ayat (1) undang-undang Nomor 13 tahun 2003 tentang Ketenagakerjaan, menyatakan bahwa pelanggaran yang dilakukan oleh buruh karena kesengajaan atau kelalaiannya dapat dikenakan denda.

g.Pada pasal 95 ayat (2) Undang-undang Nomor 13 tahun 2003 tentang Ketenagakerjaan menyatakan bahwa pengusaha yang karena kesengajaannya atau kelalaiannya mengakibatkan keterlambatan pembayaran upah, dikenakan denda sesuai dengan persentase tertentu dari upah buruh.

h. Pada pasal 8 ayat (1) Keputusan Menteri Tenaga Kerja dan Transmigrasi Nomor KEP-226/MEN/2000, tentang penetapan upah berdasarkan usulan Komisi Penelitian Pengupahan dan Jaminan Sosial Dewan Ketenagakerjaan Daerah bagi para buruh.

${ }^{35}$ Abdul Khakim, Pengantar Hukum Ketenagakerjaan Indonesia, Bedasarkan Undang-undang Nomor 13 Tahun 2003, (Cet. I; Bandung: Citra Aditya Bakti, 2006), h. 16. 
Penetapan upah minimum juga ditentukan berdasarkan kebutuhan hidup layak (atau disebut KHL), pemerintah menetapkan peraturan atau yang dikenal dengan Permenakertrans atau Peraturan Menteri Tenaga Kerja Nomor: PER-17/MEN/VIII/2005 tentang komponen dan pelaksanaan tahapan pencapaian kebutuhan hudup layak, sekaligus sebagai aturan dalam pelaksanaan dari pasal 89 ayat (4) undang-undang No. 13 tahun 2003 tentang ketenagakerjaan yang berbunyi:

\section{Kesimpulan}

Berdasarkan pada hasil penelitian yang penyusun lakukan, akhirnya dapat ditarik sebuah kesimpulan bahwa pelaksanaan pengupahan terhadap pekerja buruh bangunan yang terjadi di Perumahan Mapanget Griya Indah adalah sebagai berikut:

1. Pelaksanaan pengupahan yang terjadi di Perumahan Mapanget Griya Indah dibedakan menjadi 2 ada buruh harian yang upahnya dihitung perhari dan dibayarkan perminggu dari perusahaan. Dan buruh dari pemborong, pihak perusahaan memberikan upah bagi para pemborong yang dihitung perunit rumah sesuai kesepakatan dan mendapatkan upah perminggu sesuai dengan hasil kerja. Standar pembayaran upah yang diberikan oleh perusahaan yaitu pertama untuk buruh harian yang sebagai kepala tukang atau biasa disebut dengan bas mendapatkan upah sebesar Rp. 100.000,- perhari, kedua untuk buruh harian sebagai pembantu kepala tukang atau biasa disebut kenek mendapatkan upah Rp. 80.000,- perhari, sedangkan standar upah untuk buruh dari pemborong yaitu pertama untuk buruh yang sebagai kepala tukang mendapatkan upah Rp. 150.000,perhari, kedua untuk buruh pembantu kepala tukang mendapatkan upah Rp. 100.000,perhari.

2. Implikasi upah atau akibat upah yang di dapatkan oleh buruh bangunan di Perumahan Mapanget Griya Indah Mapanget. Upah yang mereka dapatkan tersebut sering tidak bisa mencukupi kebutuhan hidup mereka. Terutama bagi para buruh yang memiliki lebih dari 2 orang anak dikarenakan mereka harus memenuhi kebutuhan sehari-hari yang sekarang ini semakin mahal dan harus membiayai pendidikan sekolah anak, itu yang membuat upah yang didapatkan parah buruh itu tidak mencukupi. Sedangkan para buruh yang memiliki 2 orang anak juga merasa kebutuhan ekonomi mereka tidak terpenuhi dengan upah yang di dapatkan dari hasil pekerjaan buruh bangunan tersebut, karena menurut mereka kebutuhan ekonomi yang semakin mahal dan upah yang mereka dapatkan masih terlalu rendah untuk memenuhi kehidupan mereka.

3. Praktek pelaksanaan pengupahan yang dibayarkan setiap minggu yang terjadi di Perumahan Mapanget Griya Indah ini apabila dilihat serta dikaji dengan 
memperhatikan norma-norma dalam hukum Islam yang bersumberkan dari al-Qur'an dan Hadis, dapat dipandang dan dapat disimpulkan bahwa pelaksanaan sistem pengupahan buruh di Mapanget Griya Indah sah, tidak bertentangan dengan normanorma islam Sedangkan dalam pembayaran upahnya perusahaan ini belum menerapkan sistem pembayaran yang adil dan merata kepada buruh harian dan buruh dari para pemborong sesuai dengan syariat Islam yaitu upah perlu ditentukan secara adil dan tidak dilakukan dengan sewenang-wenangnya. Keadilan Islam tidak membenarkan jika seorang pekerja/buruh yang telah membanting tulang dan bercucuran keringat, tidak mendapatkan upah dari jerih payahnya itu dikurangi, atau ditunda pemberiannya. Kadar upah buruh yang adil adalah yang setimpal dengan bidang kerja bergantung pada kualitas buruh yang merangkumi aspek fisikal, kemahiran latihan dan mentalnya dan kebolehannya melebihi kadar keperluan menampung perbelanjaan diri dan keluarganya. 


\section{DAFTAR PUSTAKA}

Ahmad, Mustaq. Etika Bisnis Islam. Cet. III; Jakarta: Pustaka Al-Kautsar, 2005.

Al-Assal, Muhammad Ahmad \& Karim, Abdul Ahmad Fathi. an-Nidzaamul Iqtishaadi Fil Islam Mabaadi-Uhu Wahdaafuhu, diterjemahkan oleh Abu Ahmadi dan Anshori Umar Sitanggal dengan Judul Sistem Ekonomi Islam, Prinsip-prinsip dan Tujuannya. Surabaya: Bina Ilmu Offset, 1980

Al-Harits, Ahmad bin Jaribah. Fikih Ekonomi Umar bin Al-Khatab. Cet. 1; Jakarta Timur: KHALIFA Pustaka Al-Kautsar Grup.

Al-Qaswiniy, Al Hafidz Abi Abdillah Muhammad bin yasid. Sunan Ibnu Majah, Juz II, No hadis 2443,Kairo: Dakeahlian r Al-Hadist, t.t.

Al-Zuhaily, Wahbah. Al-Fiqih al-Islami wa Adillatuh. Jilid. IV; Beirut: Dar al Fikr, 1989

An-Nabhani, Taqyuddin. Membangun Sistem Ekonomi Alternatif Ekonomi Alternatif Perspektif Hukum Islam. alih bahasa Muhammad Maghfur Wahid, Surabaya: Risalah Gusti 1996.

Asyhadie, Zaeni. Hukum Kerja Hukum Ketenagakerjaan Bidang Hubungan Kerja. Jakarta: PT RajaGrafindo Persada, 2007.

Basyir, Azhar Ahmad. Asas-Asas Hukum Mu'amalah (Hukum Perdata). Cet. II; Yogyakarta: FH UII, 2004.

Basyir, Azhar Ahmad. Refleksi atas Pemikiran Keislaman. Cet. IV; Bandung: Mizan, $1416 / 1996 \mathrm{M}$.

Departemen, Pendidikan \& Kebudayaan. Kamus Bahsa Indonesia. Ed. I; Jakarta: Modern English Press, 1991.

Djojo Hadikusumo, Sumitro. Perkembangan Pemikiran Ekonomi. Jakarta: yayasan Obor Indonesia, 1991.

Haroen, Nasrun. Fiqh Mu'amalah. Cet. I; Jakarta: Gaya Media Pratama, 2000.

Hasan, Ali M. Berbagai Macam Transaksi dalam Islam. Ed. I. Cet. I; Jakarta: Raja Grafindo Persada, 2003.

Hassan, Kastin Surtahman. Tenaga Buruh dan Upah dalam Islam. Ghafar Islamil, 2000. 
Husni, Lalu. Pengantar Hukum dan TenagaKetenagakerjaan Indonesi. Ed. Revisi. Cet. 9; Jakarta: PT. Raja Grafindo Persada, 2009.

http://manadopostonline.com/UMP-Sulut, 2014. Di ambil hari Minggu tanggal 8 Februari 2015.

Http://eva-avgvsta.blogspot.co.id/2012/11/welfare-state.html. Di ambil hari kamis tanggal 4 Februari 2016, pukul: 13.00

Khakim, Abdul. Aspek Hukum Pengupahan, Bandung: Citra Aditya Bakti, 2006.

Khakim, Abdul. Pengantar Hukum Ketenagakerjaan Indonesia, Bedasarkan Undang-undang Nomor 13 Tahun 2003. Cet. I; Bandung: Citra Aditya Bakti, 2006.

Koestner, Paul Heinz. Mengenai Ricardo dalam Buku Terjemahan Tokoh-Tokoh Ekonomi Mengubah Dunia. Jakarta: Gramedia, 1988.

KUHPerdata pasal 1601a. cet.1; Jakata: Permata Press 2008.

Mannan, M. A. Islamic Economics; Theory and Practice. Ed. I Jakarta: PT Intermasa, 1992.

Munawir, Warson Ahmad. Al-Munawir: Kamus Arab-Indonesia. Cet. 14; Surabaya: Pustaka Progressif, 1997.

Nasution, S. Metode Research (Penelitian Ilmiah). Ed. I, Cet. II; Jakarta: Bumi Aksara, 1996.

Pasal 1 ayat (30) Undang-undang Ketenagakerjaan Nomor 13 Tahun 2003, bab 1 Ketentuan Umum, Bandung: Nuansa Aulia, 2005.

Pasaribu, Chairuman \& Lubis, K. Suhrawardi K. Hukum Perjanjian dalam Islam. Cet. III; Jakarta: Sinar Grafika, 2004.

Purwadarminta, W.J.S. Kamus Umum Bahasa Indonesia. Cet. V; Jakarta: Balai Pustaka, 1976

Qardhawi, Yusuf. Norma \& Etika Ekonomi Islam. Cet. I; Jakarta: Gema Insani Press, 1997.

Rahman, Afzarlur. Doktrin Ekonomi Islam. jilid. II; Yogyakarta: Dana Bhakti Wakaf, 1995.

RI, Departemen Agama Yayasan Penyelenggara Penerjemah. Al-Qur'an, Al-Qur'an dan Terjemahannya. Jakarta: PT. Intermasa, 1992.

Rozalinda. Fiqh Muamalah dan Aplikasinya Pada Perbankan Syariah. Cet. I; Padang: Hayfa Press, 2005.

Rusd, Ibnu. Bidayatul Mujtahid, Alih bahasa M.A. Abdurrahman \& A. Haris Abdullah. Cet I; Jakarta: Asy-Asyfa, 1990. 
Sabiq, Sayyid. Fikih Sunnah V. Cet. III; Jakarta: Pena Pundi Aksara, 2011.

Salim, Peter \& Yenny Salim. Kamus Bahasa Indonesia. Ed. I; Jakarta: Modern English Press, 1991.

Satori, Djam'an \& Komariah, Aan. Metodologi Penelitian Kualitatif. Cet.3; Bandung: Alfabeta. 2011.

Shodik, Nur Ahmad. Tinjauan Hukum Islam Terhadap Upah Buruh Tani Di Desa Rejasari Kota Banjar Jawa Barat. skrispsi tidak diterbitkan. Yogyakarta, Fak. Syariah, IAIN Sunan Kalijaga, 2008.

Siden, Wahyuni Sri. Sistem Upah Buruh Cengkeh dalam Prespektif Ekonomi Islam diDesa Nuangan induk Kecamatan Nuangan. penelitian tidak diterbitkan. Manado, Fak Syariah, STAIN, 2012.

Subekti. Aneka Perjanjian. Bandung: Alumni, 1984.

Sudjana, Eggy. Bayarlah Upah Sebelum Kering Keringatnya. Jakarta: PPMI, 2000.

Sugiyono, Metode Penelitian Kuantitatif, Kualitatif, dan R\&D, Cet. XVIII;Bandung: Alfabet, 2013

Suhrawardi, K. Lubis. Hukum Ekonomi Islam. Ed.1, Cet 3; Jakarta: Penerbit: Sinar Grafika, 2004.

Suryabrata, Sumardi. Metodologi Penelitian. Ed. I, Cet. 23; Jakarta: Rajawali Pers, 2012.

Syarifuddin, Amir. Garis-Garis Besar Fiqih. Jakarta: Prenada Media, 2003. 